\title{
“Kunstlehre” and Applied Phenomenology
}

\author{
Wen-Sheng Wang \\ Department of Philosophy, National Chengchi University, Taipei, Taiwan \\ Email: wswang@nccu.edu.tw
}

Received March 5 ${ }^{\text {th }}$, 2013; revised April 10 $0^{\text {th }}$, 2013; accepted April 20 $0^{\text {th }}, 2013$

Copyright (C) 2013 Wen-Sheng Wang. This is an open access article distributed under the Creative Commons Attribution License, which permits unrestricted use, distribution, and reproduction in any medium, provided the original work is properly cited.

\begin{abstract}
This article attempts to clarify the ambiguity or double sense of "Kunstlehre" by Husserl and Gadamer, and emphasizes "Kunstlehre" as pure science that originated in Aristotle's evaluation of theoría, and as fine art, or as the nature or quasi-nature of "as if”, according to Kant's idea. Aristotle's concept of phrónesis will be also regarded as a kind of natural "as if”, and considered as "Kunstlehre". Gadamer's philosophical hermeneutics makes a high level or deep theoretical reflection on the "Kunst" of understanding. He founds his hermeneutics under phrónesis, which will be discussed in detail. Regarding the application of "Kunstlehre" to a practical research, this article shows a contribution by Hersch, and explains how phrónesis is actualized in a case study by him. In the end, "Kunstslehre" will be pointed out as a process of exercise with time whereby Sensus communis functions as a principle (arché) of Gadamer's hermeneutics, and makes the process of the formation of phrónesis possible.
\end{abstract}

Keywords: Kunstlehre; Phenomenology; Husserl; Gadamer; Phrónesis; Sensus Communis; Applied Phenomenology

\section{Introduction}

Why do I bring the two terms "Kunstlehre" and "applied phenomenology" together?

When I first encountered the term "Kunstlehre" in phenomenological texts or contexts, I found it indicates, as great phenomenologists, such as Husserl or Gadamer (if we see hermeneutics also as a stage of the whole phenomenological movement) pointed out, that phenomenology is an applicable philosophy, which however must not be limited to a specific or concrete domain. It means phenomenology is not a technical knowledge. The usage of "Kunstlehre" actually implies the ambiguity of phenomenology.

Then, through discussions with phenomenologists and direct experience with practical phenomenological research in a hospital $^{1}$, I discovered that there are several research methods based on different phenomenological theories, such as Husserl's transcendental phenomenology ${ }^{2}$ or Heidegger's fundamental ontology ${ }^{3}$. There are often discussions regarding whether an ap-

${ }^{1}$ I have practiced a research project "Recovery of the phenomenological meaning for the technological psychotherapy” from August 2002 to October 2004 , in a state-run hospital, supported by the National Science Counsel of Taiwan. Please see my article: "Art as a Way of the Recovery from Techne to Ethos-Phenomenological Approach to Indigenous Mental Healing in Taiwan," selected Essays from Asia-Phenomenology 2005-Vol.1, Part 2, Nr. 25 Zeta Books, CARP, 2007. 12.

${ }^{2}$ For example: Moustakas, C.: Phenomenological Research Methods. Thousand Oaks/London/New Delhi: International Education and Professional Publisher, 1994.

${ }^{3}$ For example: Hersch, Edwin L. (2003): From Philosophy to Psychotherapy a Phenomenological Model for Psychology, Psychiatry, and Psychoanalysis, Toronto, Ontario, Buffalo, N.Y.: University of Toronto Press; Benner, Particia (1994): "The Tradition and Skill of Interpretive Phenomenology in Studying Health, Illness, and Caring Practices”, in: Interpretative Phenomenology, Embodiment, Caring, and Ethics in Health and Illness, editor: Petricia Benner, Thousand Oaks, Calif.: Sage Publications, pp. 99-127. propriate phenomenological research method exists. Besides, I found that, since any practical phenomenological research aims at gaining an essential meaning of its specific topic, the meaning in the end manifests an ethical character.

Moreover, for a more profound understanding, "Kunstlehre" should be raised on the philosophical level, with both practical and theoretical interests, not for the sake of simple knowledge, but for the sake of the arete, practical "being and action." 4 This author takes "Kunstlehre”, in a general or philosophical sense, followed by a connection with Aristotle's concept of phrónesis.

Finally, research methods used in applied phenomenology as "Kunstlehre" must not be regarded as a simple technique. They should be raised to become "Kunstlehre" as philosophia in relation to arete and phrónesis. This state indicates the researched meaning is characterized by ethics, and the researchers engaged in a learning process in order to gain the meaning.

The following discussion is divided into two parts. The first is this paper's review of the conception of "Kunstlehre", by Husserl and Gadamer, which shows the ambiguity of their exposition of this notion, as well as their position in both practical and theoretical phenomenology, in order to justify my former assertion. The second is this paper's reflections on applied phenomenology, which provides an example to manifest the significance of a research method becoming "Kunstlehre" in a philosophical sense.

\section{Husserl's Discussion of "Kunstlehre”}

Husserl raised a question in Prolegomena to Pure Logic of

${ }^{4}$ This saying is by Gadamer in his discussion on hermeneutics and rhetoric as "Kunstlehre", which however should be raised on the level of philosophia regarding Aristotle's practical philosophy. In: Gadamer, H.-G.: Wahrheit und Methode-Ergänzungen \& Register, Tübimgen: Mohr, 1986, S. 290.I am going to follow up later. 
his Logical investigations: Is logic a theoretical or a practical discipline ("Kunstlehre")? Husserl's idea of pure logic was a "crystal-clear theory, wherein, the functions of all concepts and sentences are fully intelligible, all presuppositions are exactly analyzed, and are entirely raised above all theoretical doubt" Nevertheless, is pure logic at the same time not a practical discipline?

For Husserl, it is doubtless that logic, as a normative discipline and theory of science, (Wissenschaftslehre) is certainly "Kunstlehre", as logic can be used to show truth or probability that is otherwise hidden in knowledge, thus, logic is a technical implement (künstliche Hilfsmittel) ${ }^{6}$. Further, logic investigates what veritable and valid sciences should be, what constitutes the idea of science, in order that we can measure whether the empirical sciences correspond with, approach, or infringe upon an idea. A method of that measure of logic is "Kunstlehre"7.

When logic is only a "Kunstlehre," and not a "crystal-clear theory," it lies that the logic does not fill the condition of the theory, as mentioned above, but, since pure logic is a theoretical discipline, is it a "Kunstlehre" as well? Although Husserl aims at delineating a new, purely theoretical science, which is nothing but pure logic, and it builds the "all-important foundation for any "Kunstlehre" of scientific knowledge," 8 is the pure logic itself, a "Kunstlehre”?

The same question can be raised regarding Husserl's discussion of ethics. In Vorlsungen über Ethik und Wertlehre 19081914, we see Husserl's idea of pure ethics as the essential foundation of "Kunstlehre" human actions; and this "Kunstlehre" refers to mere empirical ethics, or according to Husserl: "the ethics which are regarded only as a technology (Technologie) that leans on psychology and biology." Thus, we could ask, on one hand, is ethics a theoretical discipline or "Kunstlehre," and on the other hand, is pure ethics itself, a "Kunstlehre"?

Husserl's Einleitung in die Ethik, of the twenties, seemed to provide a clear answer, as the ambiguity of his exposition of "Kunstlehre" could be seen. It indicates, however, Husserl's idea of pure science is probably a form of "Kunstlehre".

Husserl sees the problem as a simple differentiation between "Kunstlehre" and theoretical science, as did Brentano; especially as the construct of this difference is created according to the following criterion: "Kunstlehre" or practical discipline is for practical interest, and theoretical science is for theoretical interest. Serving a practical purpose, "Kunstlehre" brings heterogeneous forms of knowledge together; however, in the theoretical science, the knowledge is united in a homogeneous form. Nonetheless, there are ambiguity and vagueness in that criterion $^{10}$.

Since theoretical interest is an interest in the truth for the sake of truth, is it not at the same time a practical interest, as it aims at realizing the truth as a purpose, as any non-theoretical interest does? ${ }^{11}$

\footnotetext{
${ }^{5}$ Husserl, E.: Logische Untersuchungen I: Prolegomena zur reinen Logik, Tübingen: Niemeyer, 1980, S. 10

${ }^{6}$ Ibid. S. 16; here we see a simple definition of logic as "Kunstlehre".

${ }^{7}$ Ibid. S. 26; here we see another concrete definition of logic as "Kunstlehre".

${ }^{8}$ Ibid. S. 8.

${ }^{9}$ Husserl, E.: Vorlesungen über Ethik und Wertlehre, 1908-1914, Hua. XXVIII, Hrsg.: Ullrich Melle, Dordrecht/Boston: Kluwer, 1988, S. 13.

${ }^{10}$ Husserl, E.: Einleitung in die Ethik : Vorlesungen Sommersemester 1920/ 1924, Hua. XXXVII, Hrsg.: Peucker, H., Dordrecht, The Netherlands/Boston, Mass.: Kluwer Academic Publishers, 2004, S. 13-15.

${ }^{11}$ Ibid. S. 16.
}

Is "Kunstlehre" contrary to the concept of science? As technology, "Kunstlehre" is different from "Kunst” (technique), and consists of a united system of sentences. The sentences refer to the assignment of the means to the purpose, namely they refer to the rules of applying a theory to praxis. "Kunstlehre" contributes to the scientific foundation of these rules, and thus, can be characterized as a science. Regarding the question whether "Kunstlehre" is a science or not, or if we should further differentiate theoretical and practical science, Husserl saw a vagueness in that discussion, and thought it originated in the ambiguity of the concept of "Kunstlehre"12. This ambiguity causes Brentano's simple differentiation between "Kunstlehre" and theoretical science, according to the criterion mentioned above $^{13}$.

According to Husserl, to clarify the ambiguity in the concept of "Kunstlehre" is very important, because pure science, like pure logic and pure ethics, can be justified and differentiated from the "authentic 'Kunstlehren' of scientific knowledge and ethical action" (underlined by author) ${ }^{14}$. In regard to this statement, one could ask: Is pure science a "Kunstlehre," in an inauthentic sense? The answer seems to be "yes", as we see by Husserl's clarification, a double sense (Doppelsinn) of the concept of "Kunstlehre," as shown by the following.

At first, "Kunstlehre" is purposed "to give scientifically grounded advices, prescriptions, and practical rules”, and "does not service theoretical knowledge," as "its attitude is not theoretical," whereas, "Kunstlehre" statements are "not theoretical sentences," but rather, are "a system of practical sentences."15 Such words still refer to the "authentic Kunstlehren."

However, Husserl guides us to conceive "Kunstlehre" in another sense, by way of the following considerations: As a real scientific discipline, "Kunstlehre" has a deep foundation in an a priori position. Hence, every theoretical statement can be a priori changed into a practical; conversely, every practical sentence can be changed into theoretical ${ }^{16}$.

In this regard, Husserl declares "Kunstlehre" "in a new sense", namely "in the sense of true and pure scientific disciplines." ${ }^{17}$ The context of Husserl's discussion manifests the following; He emphasizes "Kunstlehre" in a sense of pure science in order to show that, on one hand, "Kunstlehrer" not only thinks of practical advices, but can also pursue "its own theoretical totality of truths that are related to the practical themes;"18 on the other hand, he wants to show us that pure theory is "out of its own desire," also theory of praxis ${ }^{19}$. Above all, and in essence, Husserl shows: “(...) Just pure science in limitless theoretical interest, and carelessly oversees all practical claims, and afterwards qualifies supreme triumph over practical contribution"20.

As result, Husserl claimed in Prolegomena to Pure Logic and Einleitung in die Ethik that, pure logic or pure ethics can encompass the whole possible praxis regarding logical or ethical disciplines ${ }^{21}$. Naturally, in his early Vorlesungen über Ethik

\footnotetext{
${ }^{12}$ Ibid. S. $18-19$

${ }^{13}$ Ibid. S. $15-16$

${ }^{14}$ Ibid. S. 19.

${ }^{15}$ Ibid. S, 20-21.

${ }^{16}$ Ibid. S. 21-22

${ }^{17}$ Ibid. S. 23.

${ }^{18}$ Ibid. S. 22

${ }^{19}$ Ibid. S. 25.

${ }^{20}$ Ibid. S. 26.

${ }^{21}$ Husserl, E.: Logische Untersuchungen I: Prolegomena zur reinen Logik, S. 227ff.; E. Husserl: Einleitung in die Ethik, S. 30-32.
} 
und Wertlehre, Husserl had already declared the idea of the pure ethics ${ }^{22}$.

At this point, I want to make the following remark on Vorlesungen über Ethik und Wertlehre. There are some critiques of this work, who believe that Husserl emphasizes too much on the formal axiology and formal ethics, as he treated it by a comparison with the formal logic, and neglects discussions regarding material axiology and ethics ${ }^{23}$. However, we must understand that formal ethics is nothing more than pure ethics, and can be regarded as a "Kunstlehre" sense of pure science; while material ethics are "Kunstlehre" in another sense. In his early Vorlesungen, Husserl aimed at developing pure ethics, which however, encompassed material ethics, and hence we can read in text, that neither idealistic ethics nor empirical ethics can be characterized as pure ethics. Pure ethics accepts complete, rather than only parts, of understanding and feeling, and how both parts are synthesized is the point of Husserl's treatment of pure ethics ${ }^{24}$. It is related to how the double senses of "Kunstlehre" are clarified and established; therefore, we should take notice of the synthesis of both senses of "Kunstlehre," rather than simply making a critique, as mentioned above.

Husserl's emphasis on the pure science originates in Aristotle's evaluation of the theoría, which is the supreme level of the natural purpose through the development of form from matter. I prefer to understand "Kunstlehre" as an instruction of how "Kunst" in the sense of technique becomes "Kunst" in the sense of fine art. Technique (téchne) is contrary to nature (phýsis), whereas, fine art is a quasi-nature, and is, according to Kant's Critique of Judgment, "A product of fine art must be recognized as technique and not nature. Nevertheless, the finality in its form must appear just as free from the constraint of arbitrary rules as if it were a product of mere nature.,25

The "Kunstlehre," in a double sense, corresponds to the instruction of "Kunst" as technique, as well as "Kunst" as fine art, or, as a quasi-nature or nature of "as if.” Regarding "Kunstlehre" as pure ethics, how can it be understood as the nature of "as if"? It is also based on Aristotle's thoughts of ethics.

In The Nicomachean Ethics, Aristotle pointed out that moral virtue is neither "engendered by nature" nor "contrary to nature."26 Moral virtue results from the formation of good habits. It is not a feeling like being (páthos) directly engendered by nature, but is an actualization of our potential faculties (dýnamis); it requires a learning process, guided by human reasoning, in order that good habits are settled, and become our natural state, which is called hexis. Virtue belongs to the category of hexis; this nature state is our second nature, and is neither engendered by nature, nor contrary to nature ${ }^{27}$.

The above statement, "guided by human reason," is according to Aristotle's words: human "deliberation" and "choice”

\footnotetext{
${ }^{22}$ Husserl, E.: Vorlesungen über Ethik und Wertlehre, S. 13.

${ }^{23}$ Melle, U.: "Edmund Husserl: From Reason to Love", in: J. J. Drummond and L. Embree (Ed.): Phenomenological Approach to Moral Philosophy: A Handbook, Dordrecht/Boston/London: Kluwer Academic Publishers, 2002, pp. 229-248; Donohoet, J.: Husserl on Ethics and Intersubjectivity: From Static to Genetic Phenomenology, New York: Humanity Books, 2004, pp. $127 \mathrm{ff}$.

${ }^{24}$ Ibid. S. 60-69.

${ }^{25}$ Kant, I.: Kritik der Urteilskraft, Hrsg.: K. Vorländer, Hamburg: Meiner, 1974, S. 159.

${ }^{26}$ Aristotle: The Nicomachean Ethics, translated by J.A.K. Thomson, England: Penguin, 2004, 1103a, 20-26.

${ }^{27}$ Ibid. 1103a 16-20; 1105b 20-1106a 25; and see A.K. Thomson's interpretation of hexis, p. 311.
}

"lie in our power."28 Guiding or even overcoming our desires, which lie in our power, with time can become a habit. It is in view of moral virtues that direct the formation of good habits. In another view, all moral virtues are guided by practical, intellectual virtues, and these are nothing more than prudence (phrónesis) $^{29}$. The phrónesis self is a higher level of our natural state, which also results from the formation of good habits. However, habits are not material; they are formal in regard to the abilities of individual judgment. Riccardo Dottori, in his article "The Concept of Phrónesis by Aristotle and the Beginning of Hermeneutic Philosophy,” states, “(...) it (phrónesis) is a continuous exercise, a habitus which needs to be acquired with time." ${ }^{30}$ He also pointed out that phrónesis means "being able to judge." 31 "Kunstlehre" as pure ethics is related to phrónesis, which is an important issue in Gadamer's conception of "Kunstlehre."

\section{Gadamer's Discussion of "Kunstlehre”}

In Truth and Method, Gadamer introduced us to a concept of "Kunstlehre," as follows: "Kunstlehre" serves the technique of understanding (Kunst des Verstehens) through theoretical reflection; we found it regarded such understanding of philological texts of historical times, and of theological text in the times of Patristic and Reformation. Regarding this task, hermeneutics of philology and theology is a "Kunstlehre." Schleiermacher names his hermeneutics as "Kunstlehre," and "in another total systematic sense." His hermeneutics not only serve the praxis of philologist and theologians; it aims at gaining a theoretical foundation of the hermeneutic treatment that is common to the all philologist and theologians ${ }^{32}$.

To explain Schleiermacher's Hermeneutics, or "Kunstlehre", in a new sense is not the topic of this paper, but obviously, Schleiermacher offered theoretical reflection on the technique of understanding at a higher level than previously presented. According to Husserl's discussion of "Kunstlehre" in a double sense, Schleiermacher's conception touches on "Kunstlehre" in the sense of pure science, however, it seems not far enough for Gadamer.

Gadamer aims at grounding philosophical hermeneutics, which aim lies in the theoretical reflection on the technique of understanding at a much higher level than by Schleiermacher. The point is that a self-critique is exercised regarding our understanding of others ${ }^{33}$. As a result, Gadamer offers an important statement: "Understanding means at first understanding each other. (Vertstehen heißt zunächst, sich miteinander verstehen.);" in other words: "Understanding is at first agreement. (Verständnis is zunächst Einverständnis)."34 Thus, the term sensus communis, for Gadamer, is the principle of his philosophical hermeneutics or conception of "Kunstlehre" in the sense of pure science, as mentioned by Husserl. We will see that Gadamer's conception of "Kunstlehre" is based on ethical

\footnotetext{
${ }^{28}$ Ibid. 1113a 2-4, 11-12.

${ }^{29}$ Ibid. 1177a 10-14.

${ }^{30}$ Dottori, R.: "The Concept of Phronesis by Aristotle and the Beginning of Hermeneutic Philosophy”, in: Etica \& Politica/Ethics \& Politics, XI, 2009, 1, pp. 301-310, p. 307.

${ }^{31}$ Ibid. P. 301.

${ }^{32}$ Gadamer, H.-G.: Wahrheit und Methode-Grundzüge einer philosophischen Hermeneutik, Tübimgen: Mohr, 1990, S. 182.

${ }^{33}$ Gadamer, H.-G.: Wahrheit und Methode-Ergänzungen \& Register, S. 116.

${ }^{34}$ Gadamer, H.-G.: Wahrheit und Methode-Grundzüge einer philosophischen Hermeneutik, S. 183.
} 
meanings, as related to the concept of phrónesis.

Gadamer reminds us to note that the dialectic of Plato is "Kunstlehre;" however, it is different from "Kunstlehre" as professional knowledge (Fachwissen) or mathematical science, as the dialectic inquires after the real being or the highest $\operatorname{good}^{35}$. Gadamer also makes it clear that the practical knowledge (phrónesis) of Aristotle is neither technical knowledge (téchne) nor theoretical knowledge, as phrónesis is practiceoriented, and therefore, is a reflection upon specific rules of human and social practices, thus, practical knowledge is in the form of "general" and "theoretical" 36 .

The difference between phrónesis and téchne is precisely analyzed by Gadamer, and he regards it as a "kind of model of problems that lie in hermeneutic tasks. ${ }^{\text {37 }}$ The point is: hermeneutics is like phrónesis, not the simple application of an already possessed general theory to a specific concrete situation, as if we could interpret a text by the application of a general meaning, or behave according to the application of a general ethical knowledge, relevant to our specific situation; however, we are always in individual and specific situations. There is no temporal distance between a pre-given general theory and its application to a concrete situation, as without the concrete situation, it is nothing more than ethical knowledge or the interpretation of a meaningless text ${ }^{38}$.

Hence, Gadamer pointed out that, ethical knowledge cannot be learned, if we define learning as determined by a theory that is independent of the situation. Ethical knowledge cannot act as a pre-given general theory and determine an individual behavior in a situation, and is, contrarily, demanded by the individual in an individual situation ${ }^{39}$. Ethical knowledge does not refer to an object outside the individual; rather, it belongs to the individual $^{40}$, regarding the individual's existence. Dottori says, "It is not possible to learn how to exist. Phrónesis is, therefore, everybody's rational reflection on what is useful for himself, what serves for their life." 41

Further, because ethical knowledge is not an objective theory, as an end goal in the case of technical knowledge, which can be reached by us through some right means, there is no clear difference between end and means regarding ethical knowledge. Such character is already manifested in Aristotle's determination of phrónesis. Ethical knowledge includes means and end, as it deals with the rightly living self in general, and is the same knowledge present in all individual situations to answer. To differentiate ethical knowledge and individual experience is meaningless ${ }^{42}$.

Gadamer pointed out that Aristotle, in The Nicomachean Ethics, mentions the concept of "understanding” (sýnesis): "Understanding is set up as a modification of the virtue of ethical knowledge, so far as it here does not refer to myself. Hence, 'sýnesis' clearly means the ability of ethical judgment." 43 Aristotle stated precisely that a sphere, which sýnesis and phrónesis

\footnotetext{
${ }^{35}$ Gadamer, H.-G.: Wahrheit und Methode-Ergänzungen \& Register, S. 252, 306.

${ }^{36}$ Ibid. S. 252-253.

${ }^{37}$ Gadamer, H.-G.: Wahrheit und Methode-Grundzüge einer philosophischen Hermeneutik, S. 329.

${ }^{38}$ Ibid. S. 318, 322.

${ }^{39}$ Ibid.

${ }^{40}$ Ibid. S. 319-321.

${ }^{41}$ Dottori, R.: "The Concept of Phronesis by Aristotle and the Beginning of Hermeneutic Philosophy”, p. 306.

${ }^{42}$ Gadamer, H.-G.: Wahrheit und Methode-Grundzüge einer philosophischen Hermeneutik, S. 326-328.

${ }^{43}$ Ibid. 328.
}

deal with, is the same, but they are not the same, "because prudence is imperative (...), and understanding only makes judgments." 44 For the former deals with ethical knowledge, while the later with theoretical, technical, and ethical knowledge.

If we take further notice of Aristotle's words, we can determine what Gadamer discussion intended to express; in Dottori's words, "Hermeneutics is possible only on the basis of phrónesis." ${ }^{45}$ Understanding has little to do with phrónesis, as on one hand, it can relate to technical and theoretical knowledge; while on the other hand, it can be a poor understanding. However, when people are referred to as "good at understanding,” or having "sympathetic," and even "mature” judgment, they are at the same time called "prudent." ${ }^{46}$ Thus, Gadamer offers a statement in a similar sense, "We obviously praise the understanding of someone, if he (she) by judgment puts himself (herself) in the full concrete position where he (she) has to act." ${ }^{47}$ A good understanding presupposes the agreement.

The discussion above manifests that Gadamer makes a deep theoretical reflection on the technique of understanding, and it is based on the concept of phrónesis. However, just as the question is raised: "Is phrónesis different from téchne, a "Kunstlehre” in a special sense?" so is to ask: Is Gadamer's hermeneutics self a "Kunstlehre", when it is distinguished from the traditional hermeneutics as "Kunstlehren"?

We can see the dialectic by Plato is "Kunstlehre." Gadamer shows Aristotle differentiates among theoretical science, téchne, and phrónesis, however, he points out that Aristotle really has not given in to understanding phrónesis as a "Kunstlehre.” For example: Aristotle names practical philosophy as poietike philosophia ${ }^{48}$.

Gadamer emphasizes that rhetoric is not only a technique, but a philosophy of human life. Aristotle's conception originally followed Plato's dialog Phaidros. Plato stressed here that a rhetorician must know where and when (also how) he should speak $^{49}$. It manifests again the importance of a situation, as mentioned above, individual situations demand and answer ethical knowledge, or a good understanding lies in that when we put ourselves in the full concrete situation where we have to act, or, a deep theoretical reflection on the technique of understanding explicates "Understanding is at first agreement."

This shows that the concept, which Gadamer called scopus, plays an essential role for understanding and rhetoric, and naturally for phrónesis. Scopus (Germany: Gesichtspunkt; English: viewpoint) refers to a text or a speech, to our actions regarding topos and kairos, or situations as a whole ${ }^{50}$. The process of formation of understanding, rhetoric and phrónesis is the same. However, the former two are based on the latter. Hermeneutics and rhetoric stand in a closed relationship ${ }^{51}$. If neither is mere "Kunstlehren" in the technical sense, but "Kunstlehre" in the philosophical sense, it lies in that they are based on the concept of phrónesis. Phrónesis self is also a "Kunstlehre," for it results from the formation of good habits, to be able to judge. Therefore, Dottori would like to translate "Kunstlehre" as

\footnotetext{
${ }^{44}$ Aristotle: The Nicomachean Ethics, 1143a, 9-10.

${ }^{45}$ Dottori, R.: "The Concept of Phronesis by Aristotle and the Beginning of Hermeneutic Philosophy”, p. 309.

${ }^{46}$ Aristotle: The Nicomachean Ethics, 1143a, 12-28.

${ }^{47}$ Gadamer, H.-G.: Wahrheit und Methode-Grundzüge einer philosophischen Hermeneutik, S. 328.

${ }^{48}$ Gadamer, H.-G.: Wahrheit und Methode-Ergänzungen \& Register, S. 291.

${ }^{49}$ Ibid. S. 307.

${ }^{50}$ Ibid. S. 255, 259, 282, 286, 296, 309.

${ }^{51}$ Ibid. S. 305.
} 
“competence." 52 However, this "being able to" is not a potential ability (dýnamis), but a concrete natural state (hexis), because it has been exercised and constituted. It should be also valid for the competence of hermeneutics and rhetoric.

\section{Phrónesis and Applied Phenomenology}

As mentioned above, there are several research methods in applied phenomenology, and there are often discussions regarding whether an appropriate method actually exists. The difficulty lies in that, first, the research method is neither a technique, nor the reflection on it a "Kunstlehre" in the technical sense. Secondly, the meaning, which any research topic seeks, is not through an application of a pre-given general theory to a specific situation where the researcher stays.

On the contrary, every applied phenomenologist must always be aware that their individual situation is not separated from the constitution of the wanted meaning; thus, experience and gained meaning are not separable. In this situation, the researcher asks for or demands the meaning; Gadamer said there is a form of "seeing", but not a sensuous ${ }^{53}$. It is like Husserl's or Heidegger's categorical intuition or eidetic intuition. However, according to Gadamer, the process of "fusion of horizons" (Horizontverschmelzung) ${ }^{54}$ seems to be characterized as a way of "seeing," which shows the way of understanding, namely understanding of each other, or an agreement between two individuals. It also reflects on practical research, by way of the researcher (e.g. therapist) and the research focus (e.g. patient), which co-exist in a common concrete situation (regarding topos and kairos), where they start to co-constitute the meaning of a certain theme.

In this sense, we see that Edwin L. Hersch, in From Philosophy to Psychotherapy, shows us a co-constitutional and interactional human experience model, namely "Beams-of- Lightthrough-Time”. He tries to describe the human experience as, "always experienced in a time-context within which our phenomenological worlds are constantly unfolding, expanding, and restructuring." Thus, therapist and patient are situated, on one hand, in their own dynamic world experience, and on the other hand, in their experiences of each other since their encounter. The experience of others endlessly increases its content and meaning, as this experience is not determined with a fixed worldview, but is in continuous development accompanied by the expanding world experience. Thus, he says, "Each of the participants is continuously in a co-constituting relationship to his or her experiential world as a whole, as well as in relationship with the other." 55

Hersch indicated an appropriate phenomenological research method, even though it cannot be used as the absolute objective model, it is the main point seeking awareness of being free from the determination of a pre-given theory, and how we can put ourselves in a common situation with others. This paper stresses that this process constitutes the formation of phrónesis, which hermeneutics and rhetoric are based on. In fact, Heidegger's analysis of the care (Sorge) structure in Sein und Zeit is an interpretation of phrónesis. Gadamer follows with the definition of phrónesis as "the watchfulness care for oneself (die

\footnotetext{
${ }^{52}$ Dottori, R.: "The Concept of Phronesis by Aristotle and the Beginning of Hermeneutic Philosophy”, p. 309.

${ }^{53}$ Gadamer, H.-G.: Wahrheit und Methode-Grundzüge einer philosophischen Hermeneutik, S. 327.

${ }^{54}$ Ibid. S. 312, 380, etc.

${ }^{55}$ Hersch, Edwin L.: From Philosophy to Psychotherapy, pp. 133-136.
}

Wachsamkeit der Sorge um sich selbst). ${ }^{, 56}$ His discussion regarding distinguished ethical knowledge, as mentioned above, is also his interpretation of phrónesis. Was Husserl regards as "Kunstlehre" in the sense of pure ethics and further discusses in his Ethics Lectures, manifests many ideas in relation to Aristotle's concept of phrónesis ${ }^{57}$.

In a similar context, this paper turns to Kant, who originally attempts to expose the concept of phrónesis, presented by two concepts: determinant judgment and reflective judgment. It is no wonder that Hannah Arendt regarded Kantian reflective judgment and Aristotle's phrónesis as the same thing ${ }^{58}$. This paper suggests that reflective judgment can realize phrónesis, explained through an old psychiatric tale, as told by Hersch.

The tale refers to two brothers, Joe and Bob, in a psychiatric praxis. Joe explains to the psychiatrist that Bob seems to be delusional, and insists that he is already dead. Bob tells the psychiatrist that he is dead, because all his feeling have stopped, as has his heart, and his blood has ceased to flow. Impatiently, Joe reaches into his pocket for a pen knife and jabs it into Bob's hand. While Bob looks down at his hand as the blood begins to well up and spread, Joe angrily asks him, "You see the blood. Now do you still think you're dead?” Bob calmly tells the psychiatrist: "I never would've believed it. Dead men do bleed!" 99

This tale reveals food for thought. Regarding Bob's words, he is dead because his blood has ceased to flow, the psychiatrist would cure Bob's delusion by way of Joe's method. He hopes that when Bob sees the blood, he could correct his delusion that he is dead. Naturally, the method of cure is naïve; however, this naïve cure method presupposes the truth theory of correspondence, which is at the epistemological level. Just as at this level Bob said dead men do not bleed. It follows: "do not bleed" corresponds to "dead men," however, in the end it cannot exclude that "do bleed" corresponds to "dead men."

We must notice that the epistemological level still lies in an ontological fundamental. The delusion, he is dead, referring to his situation, has an ontological fundamental. We should ask what this fundamental, namely what his delusion in general is.

A psychiatric praxis is often something presupposed, which causes the psychiatrist to construct a determinant judgment and cure practice. In this case, what determines the psychiatrist to judge and to cure is the truth theory of correspondence, and according to Hersch's analysis, the "realist-dualist-objectivistcorrespondence" position ${ }^{60}$. In this position, Joe cannot argue against Bob’s answer: “Dead men do bleed!” In fact, Bob himself believes that the two sentences; "Dead men do not bleed" and "Dead men do bleed" do not contradict each other, because he makes those judgments under a "realist-dualist-subjectivistcoherence" position ${ }^{61}$, which also lies in the ontological funda-

\footnotetext{
${ }^{56}$ Dottori, R.: "The Concept of Phronesis by Aristotle and the Beginning of Hermeneutic Philosophy”, p. 306.

${ }^{57}$ I have in my article (Wang, Wen-Sheng: "Relationship between Husserl's early ethics and Aristotle's ethics” [in Chinese], in: NCCU Philosophical Journal, Vol. 18, 2007 July, pp. 1-28.) showed that relationship between them regarding three issues: 1 . Husserl's characterizes ethics as "Kunstlehre"; 2 . Husserl argues that the judgment of values springs from affection; 3 . Husserl differentiates the concept of "will” from that of "wish". It manifests some ideas of the concept of phrónesis. See NCCU Philosophical Journal, Vol. 18, 2007 July, pp. 1-28.

${ }^{58}$ Arendt. H.: "The Crisis in Culture: Its Social and Its Political Significance” in: Judgment, Imagination, and Politics: Themes from Kant and Arendt, New York, Oxford etc.: Roman \&Littlefield Publishers INC., 2001, pp. 3-25 p. 20.

${ }^{59}$ Hersch, Edwin L.: From Philosophy to Psychotherapy, p. 97.

${ }^{60}$ Ibid. p. 126.

${ }^{61}$ Ibid. p. 127.
} 
mental.

According to Kant, we have to make reflection on our cognitive faculties (Erkenntnisvermögen) ${ }^{62}$. In this case, the psychiatrist should reflect which cognitive faculties determined his earlier judgment and treatment, which is the "realist-dualistobjectivist-correspondence"/“realist-dualist-subjectivist-coherence” position. Based on Heidegger's fundamental ontology and Gadamer's hermeneutics, Hersch presents a "realist-nondualistic-co-constitutional-hermeneutics" position ${ }^{63}$. Under this position, the psychiatrist can put himself in a common situation shared with Bob, his brother Joe, and maybe his family, etc. Together, they continuously co-constitute the meaning "Bob is dead", and the way of healing emerges from the meaning, which should also be in a continuous process.

Some termini shown here cannot be further explained. It is not the aim of this article to exactly demonstrate how e.g. Gadamer's hermeneutics is applied to a practical case. This paper regards this psychiatric tale, and a reflection upon it, to show that the Kantian reflective judgment helps us to realize Aristotle's concept of phrónesis. Take note, however, that phrónesis as a habitual "being able to judge" needs "a continuous exercise". A continuous awareness of making reflective judgments, and avoiding determinant judgments, seems able to concretize this exercise. In addition, remember Gadamer's words, "Understanding means at first understanding each other or agreement.” It implies to this author a kind of virtue, namely "respect for others." As putting ourselves in a situation shared with others would realize our understanding of each other, thus, some phanomenologists directly regard the "situatedness" (putting ourselves in the situation) as a kind of virtue. It is actually based on the connection between ethos and Dasein, according to Heidegger's thinking.

\section{Conclusion}

This paper attempts to clarify the ambiguity or double sense of "Kunstlehre" by Husserl and Gadamer. Pure science, which is in the form of either pure logic or pure ethics, by Husserl, is regarded by the author as "Kunstlehre," but is distinguished from "Kunstlehre" in the technical sense.

The author sees "Kunstlehre" in a sense of pure science, originated in Aristotle's evaluation of theoría, and understood "Kunstlehre" as fine art, or as the nature or quasi-nature of "as if”, and according to Kant's idea. Aristotle's concept of phrónesis is also a kind of natural "as if", especially as phrónesis is "a habitus, which is acquired with time". In this sense, phrónesis can be considered as "Kunstlehre".

Gadamer's high level or deep theoretical reflection on the "Kunst" of understanding brings about his philosophical hermeneutics, which begins with the words, "Understanding means at first understanding each other or agreement.” It is actualized by "putting ourselves in a situation shared with others". The word "situation" is compared by Gadamer with scopus. Both hermeneutics and rhetoric in the philosophical sense are based on the evaluation of scopus. This constitutes the formation of the two, naturally of phrónesis, which founds the former of the two.
How can be such "Kunstlehre" be applied to a practical research? This paper shows a contribution by Hersch as an example, through a psychiatric tale, this author's consideration, and by way of Kantian reflective judgment, explains how phrónesis is actualized in a case study.

"Kunstslehre" is a process of exercise with time, where we learn how to respect others, and how we understand and agree with each other. Sensus communis is an ethical term, and a principle (arche) of Gadamer's hermeneutics, beginning in the sense of dýnamis, and to realize hexis requires exercise and learning. It is the process of the formation of phrónesis. "Kunstlehre” in this sense, is both the process and result, the means and end, as it is continuously under way.

\section{REFERENCES}

Arendt, H. (2001). The crisis in culture: Its social and its political significance. In: R. Beiner, \& J. Nedelsky (Eds.), Judgment, imagination, and politics: Themes from Kant and Arendt (pp. 3-25). New York: Roman \& Littlefield Publishers Inc.

Aristotle (2004). The Nicomachean ethics. Translated by J. A. K. Thomson. London: Penguin.

Benner, P. (1994). The tradition and skill of interpretive phenomenology in studying health, illness, and caring practices. In P. Benner, (Ed.), Interpretative phenomenology, embodiment, caring, and ethics in health and illness (pp. 99-127). Thousand Oaks, CA: Sage Publications. doi:10.4135/9781452204727.n6

Donohoet, J. (2004). Husserl on ethics and intersubjectivity: From static to genetic phenomenology. New York: Humanity Books.

Dottori, R. (2009). The concept of phronesis by Aristotle and the beginning of hermeneutic philosophy. In: Etica \& Politica/Ethics \& Politics, XI/1 (pp. 301-310). Università di Trieste Dipartimento di Filosofia. http://www.units.it/etica

Gadamer, H.-G. (1990). Wahrheit und Methode-Grundzüge einer philosophischen Hermeneutik. Tübingen: Mohr.

Gadamer, H.-G. (1986). Wahrheit und Methode-Ergänzungen \& Register. Tübingen: Mohr.

Hersch, E. L. (2003). From philosophy to psychotherapy, a phenomenological model for psychology, psychiatry, and psychoanalysis. Toronto: University of Toronto Press.

Husserl, E. (1980). Logische Untersuchungen I: Prolegomena zur reinen Logik. Tübingen: Niemeyer.

Husserl, E. (1988). Vorlesungen über Ethik und Wertlehre, 1908-1914. Hua. XXVIII. Hrsg.: Ullrich Melle. Dordrecht/Boston: Kluwer.

Husserl, E. (2004). Einleitung in die Ethik : Vorlesungen Sommersemester 1920/1924. Hua. XXXVII. Hrsg.: Peucker, H., Dordrecht. The Netherlands/Boston, Mass.: Kluwer Academic Publishers.

Kant, I. (1974). Kritik der Urteilskraft. Hrsg.: K. Vorländer, Hamburg: Meiner.

Melle, U. (2002). Edmund Husserl: From reason to love. In: J. J. Drummond, \& L. Embree (Eds.), Phenomenological approach to moral philosophy: A handbook (pp. 229-248). Dordrecht/Boston/London: Kluwer Academic Publishers. doi:10.1007/978-94-015-9924-5 12

Moustakas, C. (1994). Phenomenological research methods. Thousand Oaks/London/New Delhi: International Education and Professional Publisher.

Wang, W.-S. (2007). Art as a way of the recovery from techne to ethos -Phenomenological approach to indigenous mental healing in Taiwan. Asia Phenomenology, 1, 2005.

Wang, W.-S. (2007). Relationship between Husserl's early ethics and Aristotle's ethics. NCCU Philosophical Journal, 18, 1-28.

\footnotetext{
${ }^{62}$ Kant, I.: Kritik der Urteilskraft, S. 260.

${ }^{63}$ Hersch, Edwin L.: From Philosophy to Psychotherapy, p. 132.
} 